merensuomalaisten esihistorian tutkimuksessa. [Arvio teoksesta Valter Lang: Läänemeresoome tulemised.] - Virittäjä 122 s. 601-607. https://doi. org/10.23982/vir.69835.

Korhonen, Mikno 1993: Kielen synty. Porvoo: WSOY.

LANG, VALTER 2018: Lä̈nemeresoome tulemised. Muinasaja teadus 28. Tartu: Tartu Ülikooli Kirjastus.

Ravila, PaAvo 1959: Kantakieli kielihis- torian peruskäsitteenä. - Virittäjä 63

s. $181-189$.

SArhimaA, Anneli 2018: Ei kannettavu vezi kaivos pyzy. Oikaisuja tietokirjani arvosteluun. - Virittäjä 122 s. 588-592. https://doi.org/10.23982/vir.76336.

YLIKOSKI, JUSSI 2018: The so-called relation forms of nouns in South Saami. A byproduct or remnant of Uralic * $-m p V$ ? - Finnisch-Ugrische Forschungen 64 s. 6-71.

\title{
Sosiolingvistinen teoria ja aikamme ilmiöt
}

Nikolas Coupland (toim.): Sociolinguistics. Theoretical debates. Cambridge: Cambridge University Press 2016. $458 \mathrm{~s}$.

ISBN 978-1-107-63575-3.

Silloin tällöin opiskelijan kuulee huokailevan, ettei hän ole vielä saanut muodostettua kokonaiskuvaa sosiolingvistiikasta. Tapaan vastata, että enemmän olisin huolissani vastakkaisesta tunteesta - sosiolingvistiikan tutkimuskenttä kun on siinä määrin laaja, että kokonaiskuvan muodostaminen vaatii väistämättä pidempää perehtymistä ja esimerkiksi kotimaista tutkimusta laajemman ja monimuotoisemman tutkimuskentän tuntemusta.

Sosiolingvistisiä lähestymistapoja kieleen ja yhteiskuntaan on käsitelty lukuisissa alan kokoelmissa ja käsikirjoissa, joista osa on keskittynyt erityisesti teoreettisiin ja metateoreettisiin kysymyksiin (esim. Figueroa 1994; Coupland, Sarangi \&
Candlin toim. 2001; Chambers 2009 [1995]; Auer \& Schmidt toim. 2010). Yksittäisen teoksen ei voi olettaa kattavan kuin osan sosiolingvistiikan teorioista ja tutkimuksellisista lähestymistavoista. Tässä arvioitava Nikolas Couplandin toimittama teos Sociolinguistics: Theoretical debates asettuu sosiolingvistiikan teoreettisia kysymyksiä käsittelevien keskeisten teosten joukkoon. Teos sisältää 20 artikkelia, joiden kirjoittajakunta koostuu maineikkaista, teoreetikoinakin tunnetuista sosiolingvisteistä. Teos jakautuu kuuteen osaan, joita esittelen seuraavassa pääosin teoksen etenemisjärjestyksen mukaisesti.

\section{Mistä puhutaan, kun puhutaan teoriasta?}

Teoksen toimittanut Nikolas Coupland sekä aloittaa että päättää kokoelman omilla reflektiivisillä puheenvuoroillaan, 
joista kuultaa pitkän uran tehneen sosiolingvistiikan pioneerin kokemus ja näkemys alan kehityksestä. Johdantoartikkelissa hän paitsi esittelee ja perustelee kokoelman artikkelit myös problematisoi sosiolingvistisen teorian merkitystä ja asemaa alan kehityskaarissa. Teoksen nimessä "debatti" viittaa ennen muuta kirjoittajien kriittisiin itsereflektioihin, joiden läpi teoksessa käsitellään kirjoittajien intressien mukaisia analyyttisiä ja teoreettismetodologisia kysymyksiä samalla asemoiden niitä alalla käytyihin keskusteluihin. Empiiristä analyysiä on mukana vain muutamissa artikkeleissa. Kirjoitusten enemmistö on state of the art -tyyppisiä tarkasteluita. Jokainen artikkeli on omassa lajissaan kiinnostava ja lunastaa paikkansa kokoelmassa, vaikka teoksen osien sisäinen työnjako ei kaikilta osin olekaan aivan selkeä.

\section{Sosiaalisen merkityksen teoretisointi ja kielelliset markkinat}

Johdantoartikkelia seuraa luontevasti sosiaalisen merkityksen käsittelyyn keskittyvä osa "Theorising social meaning", joka ankkuroi teosta sen jälkistrukturalistiseen perustaan. Kaikki osan neljä kirjoitusta, jotka ovat Michael Silversteinin, Penelope Eckertin, Susan Galin ja Alexandra Jaffen kirjoittamat, pohjaavat teoreettisilta lähtökohdiltaan Peircen pragmatistiseen semiotiikkaan. Näissä sosiaalisen merkityksen tutkimukselle valetaan toisentyyppinen pohja kuin lingvistien parissa laajemmin vakiintuneeseen de Saussuren strukturalistiseen merkitysteoriaan nojaavissa perinteissä. Peircen semioottinen merkkiteoria ei de Saussuren tapaan perustu lingvistiikkaan vaan yleisluontoisempaan teoriaan merkeistä ja merkkiprosesseista. Se luo pohjan niille sosiaalisen indeksisyyden teoretisoinneille, joita sosiolingvistit ovat viime aikoina kehitelleet ottaen inspiraatiota erityisesti Silversteinin (2003) indeksisten järjestysten teoriasta.
Ensimmäisen osan kontribuutiot muodostavat syvällisen kokonaisuuden erittelemällä sosiaalisten merkitysten konstruktiivisuuden ja siihen liittyvien semioottisten mekanismien teoreettista pohjaa. Jaffen artikkeli "Indexicality, stance and fields" on osan ainoa myös empiiristä analyysiä sisältävä artikkeli. Osan muissa artikkeleissa teoriavetoisesti käsitellyt indeksisyyden ja rekisteriytymisen prosessit lihallistuvat Jaffen metaindeksisessä analyysissä, jonka kohteena on eräässä tunnetussa blogissa (Stuff White People Like) tuotetut kontekstisidonnaiset, valkoihoisuuteen ja luokka-asemaan kytkeytyvät indeksiset merkitykset, niiden prosessiluonne ja tulkintamahdollisuudet. Analyysissä on samalla kyse indeksisyyden ja rekisteriytymisen teorian edelleenkehittelystä.

Siinä missä teoksen ensimmäinen osa keskittyy erityisesti mikrotason merkitysprosesseihin, toinen osa "Language, markets and materiality" kuljettaa tarkastelua makrotasolle ottamalla käsittelyyn kielen materiaalisuuden ja kielelliset markkinat. Osan kolme artikkelia käsittelevät kielen tuotteistamista (Monica Heller \& Alexandre Duchêne), kielellisten markkinoiden teoriaa (Helen Kelly-Holmes) ja kehollisuutta osana sosiolingvististä teoriaa (Mary Bucholz \& Kira Hall). Viimeksi mainitussa haastetaan kielen logosentristä määrittelyä ja peräänkuulutetaan sellaista sosiolingvististä teoriaa, jossa ilmaisullisten keinovalikoimien, tuotosten ja niitä koskevien mielteiden tarkastelu olisi kokonaisvaltaista, ulottuen lingvistisiä resursseja laajemmalle. Eleiden ja kehollisuuden huomioivia tutkimusperinteitä, kuten etnometodologista keskustelunanalyysiä, ohittamatta käsittelyssä edetään pohtimaan kehollisen toimijuuden (embodied agency) potentiaalia osana sosiokulttuurisesti suuntautunutta kielentutkimusta ja osana tulevaisuuden holistista sosiolingvististä teoriaa. 
Tilan ja liikkuvuuden problematiikka

Teoksen kolmas osa "Sociolinguistics, place and mobility" käsittelee suomalaisessakin sosiolingvistiikassa perinteisesti vahvaa liikkuvuuden tematiikkaa ottamalla käsittelyyn tila- ja kieliteoreettisia sekä terminologisia kysymyksiä. Osa koostuu kolmesta kirjoituksesta, joissa tarkastellaan liikkuvuutta koskevia ilmiöitä ja niiden empiiris-teoreettisia seurauksia sosiolingvistiikalle. Alastair Pennycookin artikkeli "Mobile times, mobile terms: Transsuper-poly-metro movement" tarkastelee kriittisesti käsitteistöä, joka on rehevöitynyt 200o-luvulla kielellistä monimuotoisuutta käsittelevän paradigmaattisen muutoksen, erityisesti superdiversiteettikeskustelun myötä (ks. Vertovec 2007; myös Blommaert \& Rampton 2011). Missä määrin on kyse "vanhan viinin uudelleen pullottamisesta" (s. 201), missä määrin todella uusista sosiolingvistisistä ilmiöistä, joiden kuvaamiseen tarvitaan uusia käsitteitä? Pennycookin mukaan osa sekä ilmiöistä että käsitteistä on vanhaa perua, mutta uudelle käsitteistölle - sellaisille kuin esimerkiksi trans-, poly- ja metrolanguaging ${ }^{1}$ - on käyttöä uusien teoreettisten ja analyyttisten sitoumusten erkaannuttamiseksi vanhemmista tutkimusperinteistä. Superdiversiteetti-käsite, jonka Vertovec (2007) kehitti monimuotoisuuden moninaistumisen käsittelemiseksi, on inspiroinut analyyttisiä lähestymistapoja, jotka ovat johtaneet kirjavaan käsiteviidakkoon. Tämä on Pennycookin mukaan tullut tarpeeseen aikana, jolloin globaaliin liikkuvuuteen palautuvat empiiriset ilmiöt ovat kannustaneet lähestymään kieliä mieluummin sekoittuvina resursseina kuin toisistaan erillisinä saarekkeina. Kun kielten sekoittuminen paikallisissa käytänteissä ymmärretään pikemmin normaalina kuin poikkeavana ilmiönä, on haluttu ir-

1. Languaging on suomennettu kieleilyksi (Lehtonen 2015: 53; Dufva, Aro, Suni \& Salo 2011). rottautua sellaisista toisten perinteiden rasittamista käsitteistä kuin vaikkapa kaksikielisyys.

Jan Blommaertin tähän osaan laatima artikkeli "From mobility to complexity in sociolinguistic theory and method" viittaa myös käsitteistön taakkoihin ja rajoittuneisuuksiin tilanteessa, jossa kirjoituksen otsikon mukaisesti esitetään teoreettismetodologista uudelleenorientoitumista sosiaalisten ilmiöiden - erityisesti sosiaalisen kompleksisuuden ja dynaamisten järjestelmien - tutkimiseksi. Sosiolingvistisen muutoksen tutkimiseksi Blommaert esittää paradigmaattista muutosta, jossa dynaamisuus ja liikkuvuus otettaisiin aidosti tutkimuksen lähtökohdaksi. David Britainin reflektio "Sedentarism and nomadism in the sociolinguistics of dialect" puolestaan ottaa kriittiseen tarkasteluun liikkuvuuden ja liikkumattomuuden tutkimukselliset ideologiat, joiden voi nähdä läpäisseen autenttisuuden ideologian ohella (ja siihen kytkeytyen) murteentutkimuksen perinteitä. Kuten Britain toteaa (s. 218), tilan kuvittelun kritiikki suhteessa maantieteessä tunnettuihin tilan käsitteellistyksiin on saapunut dialektologiseen keskusteluun viipeellä. Britain pohtii tilateoreetikkoihin nojaten paikan tulkintaa sosiolingvistisen tutkimuksen kriittisenä lähtökohtana. Hän korostaa tarvetta erottaa liikkuvuuden kasvu siihen kohdistuneen akateemisen huomion kasvusta - liikkuvuus ei erinäisten tilastojen valossa ole maailmanlaajuisesti siinä määrin tuore tai voimakas ilmiö, jollaiseksi me länsimaissa sen tällä hetkellä hahmotamme. Britain painottaa, että globaalin liikkuvuuden rinnalla on tarpeen tutkia myös paikallista, arkista ja jokapäiväista liikkuvuutta. Tutkimuskohteena viimeksi mainittu edellyttää metodologistakin kehittämistä, sillä perinteiset aineistonkeruutavat, kuten haastattelu, merkitsevät kirjaimellisesti pysähtymistä aloilleen, mikä ei välttämättä parhaiten tavoita sitä kielellistä toimintaa, joka on luonteenomaista liikkuvuudelle arjessa. 


\section{Kriittisen sosiolingvistiikan kysymyksiä}

Teoksen neljäs osa "Power, mediation and critical sociolinguistics" läpivalaisee sosiaalisen muutoksen tutkimuksen teoreettisia perinteitä ja sosiolingvistiikan kriittisiä lähestymistapoja, joissa - Sari Pietikäistä lainaten (s. 265) - kriittisyys voi ottaa monenlaisia muotoja, niin etnografisia, emansipatorisia kuin karnevalistisia. Pietikäisen artikkeli "Discourse, boundaries and change" käynnistää osan jäsentämällä kriittisen sosiolingvistiikan lähestymistapojen ja yhteiskuntakriittisyyden muotoja saamelaisuutta koskevien esimerkkien kautta.

Media ja medioituminen ovat merkittäviä ilmiöitä sosiaalisten kategorisointien, ideologioiden ja valtarakenteiden käsittelyn ja tutkimisen kannalta. Jannis Androutsopouloksen käsitekriittinen artikkeli "Media, mediation and mediatization" sopii hyvin jatkamaan Pietikäisen aloittamaa keskustelua. Androutsopoulos nostaa esiin massamedian ja uusien medioiden tarpeettoman vastakkainasettelun, josta huomauttaminen voi tällä vuosikymmenellä tuntua jo tarpeettomalta. Kritiikki on kuitenkin oikeutettua, kun ottaa huomioon, missä määrin media on jäänyt katveeseen sosiolingvistiikan teorianmuodostuksissa. Kuten Androutsopoulos huomauttaa (s. 283), variationistisessa perinteessä mediaa on tavattu kohdella enemmän kielenkäyttöön vaikuttavana tekijänä kuin kiinteänä osana variaatiokysymysten kanonisoitunutta teoriaperustaa. Androutsopoulos peräänkuuluttaakin medioitumisen edellyttämiä teoreettisia ja analyyttisiä muutoksia - erilaisten semioottisten resurssien ja ulottuvuuksien, kuten visuaalisuuden, normalisointia osana sosiolingvististä analyysiä esimerkiksi eri kielimuotojen tutkimuksessa.

Kuten useissa muissakin tämän kokoelman puheenvuoroissa, kaipaa Androutsopouloskin uusia työkaluja ja metaforia me- dioituneen, teknologiavälitteisen kielenkäytön teoreettiseen työstämiseen. Hänen kritiikkinsä variationistista sosiolingvistiikkaa kohtaan on terävää ja ymmärrettävääkin: vaikka medialla on jo kauan ennen nykyisen viestintäteknologian aikaa ollut merkittävä rooli kielenkäytön sosiaalisten merkitysten ja kieli-ideologoiden välittäjänä (Suomen oloissa ks. esim. Halonen \& Vaattovaara 2017), se ei ole saanut sosiolingvistiikassa aivan ansaitsemansa laajuista huomiota esimerkiksi kielellistä muutosta koskevissa pohdinnoissa. Teoksen ensimmäisessä osassa esitellyn, lingvistisestä antropologiasta ammentavan semioottisen teoriakehyksen astuttua sosiolingvistiikan kentälle aika mediatietoisuudelle lienee nyt kypsempi. Androutsopoulos osoittaa kyseisen viitekehyksen tarpeellisuuden käsitellessään median (tai medioiden) osallisuutta rekisteriytymisprosesseissa.

Neljännen osan päättävässä artikkelissa "Foucault, Gumperz and governmentality: Interaction, power and subjectivity in the twenty-first century" Ben Rampton keskittyy Gumperzin "uusgumperzilaiseen" tulkintaan viimeaikaisessa sosiolingvistiikassa. Hän kartoittaa Gumperzin (1982) vuorovaikutusanalyysin ja Foucault'n (1980) hallinnan teorian yhtymäkohtia ja esittää myös konkreettisia vuorovaikutuksen ja valta-asetelmien tutkimustavoitteita ja konteksteja 200o-luvun sosiolingvistiikalle. Yhtenä kiinnostavista konteksteista mainitaan koulumaailma muun muassa siksi, että se on yhä enemmän siirtymässä digitaalisiin oppimisympäristöihin, mikä muuttaa osallistumisen asetelmia.

\section{Sosiolingvistiikka ja yhteiskunnalli- nen vaikuttavuus}

Kiinnostava ja hyvin tervetullut tähän kokoelmaan on myös sen viides, tutkimuksen vaikuttavuutta ja yhteiskunnallista vuorovaikutusta käsittelevä osa "Sociolinguistics, contexts and impact". Tämä- 
kin on usean muun näkökulmaluvun tapaan kolmen artikkelin kokonaisuus. Luvun aloittaa Lionel Ween puheenvuoro "Are there zombies in language policy? Theoretical interventions and the continued vitality of (apparently) defunct concepts", joka käsittelee kielipoliittista jännitettä kahden hyvin erilaisen kielinäkemyksen välillä: yhtäältä jälkimodernin, teoreettisesti valveutuneen näkemyksen ja toisaalta maallikoiden toimintaa usein ohjaavan essentialisoivan näkemyksen välillä. Vallitseviin käytänteisiin vaikuttaminen edellyttää kielipoliittisilta kehittämistoimilta sensitiivisyyttä ja joustavuutta, strategista tasapainoilua näkemyksellisen tutkimustiedon soveltamisen ja kontekstisidonnaisen realismin välillä.

Diane Eadesin kirjoitus "Theorising language in sociolinguistics and the law: (How) can sociolinguistics have an impact on inequality in the criminal justice process?" käsittelee lakikieltä, erityisesti oikeussalikieltä ja siihen liittyviä kriittisiä, kielellisten merkitysten tulkintakysymyksiä. Hänen viestinsä on samansuuntainen kuin Weellä. Kiinnostavien esimerkkien analyysin avulla Eades osoittaa, miten tärkeää tasa-arvon kannalta olisi, että oikeuslaitosten toimintatapoja kehitettäisiin myös sosiolingvistisen tutkimustiedon varassa. Artikkelin viesti on, että tämä on mahdollista mutta edellyttää sosiolingvisteiltä kykyä käsitellä kieliteoreettisia ja vuorovaikutuslingvistisiä kysymyksiä yleistajuisesti - suhteuttaen tieteellisesti valistunutta ymmärrystä instituutiossa juurtuneisiin käytänteisiin ja kieliideologisiin ajattelutapoihin.

Ceil Lucasin ja Robert Bayleyn viittomakielen tutkimusta käsittelevä artikkeli "Quantitative sociolinguistics and sign languages: Implications for sociolinguistic theory" on jostain syystä sijoitettu Ween ja Eadesin kirjoitusten väliin. Siinä missä teoksen viidennen osan ensimmäistä ja kolmatta kirjoitusta yhdistää selvästi akateemisten tutkijoiden ja sidosryhmien vä- lisen suhteen tarkastelu, keskittyy Lucasin ja Bayleyn artikkeli tarkastelemaan erityisesti labovilaisen variaatioanalyysin sovelluskelpoisuutta viittomakielen tutkimukseen ja viittomakielen paikkaa osana sosiolingvististä teorianmuodostusta. Artikkelille luontevampi paikka olisi ollut teoksen toinen osa, jossa käsitellään kielen kehollisuutta. Viidenteen osaan sijoitettuna tämän kontribuution voinee tulkita korostavan tarvetta rajojen ylityksiin ja yleistajuistamiseen myös alan sisäisissä keskusteluissa.

\section{Sosiolingvistisen teorian evoluutio}

Teoksen viimeisen osan "The evolution of sociolinguistic theory" muodostavat Couplandin päätäntöartikkelin ohella Allan Bellin ja Barbara Johnstonen läpileikkaavat katsaukset sosiolingvistiikan kehityksestä. Tämän mandaatin he ovat saaneet alan keskeisimpien tieteellisten lehtien pitkäaikaisina toimittajina. Bell on toiminut Journal of Sociolinguisticsin päätoimittajana perustettuaan lehden yhdessä Couplandin kanssa vuonna 1996 ja Johnstone toisen ja samalla alan vanhimman aikakauslehden, Language in Societyn, päätoimittajana vuosina 2005-2014. Molemmilla on siten laaja kuva alan sisäisistä tieteellisistä keskusteluista, joihin he ovat myös itse osallistuneet painavilla teoreettisilla kontribuutioillaan - Bell (1984) erityisesti klassikkoartikkelillaan "Language style as audience design" ja Johnstone tuomalla monitieteisesti sivistyneen tilan tulkinnan sosiolingvistiikkaan.

Kirjoituksessaan "Language theory in contemporary sociolinguistics: Beyond Dell Hymes?" Johnstone tarkastelee alan kehitystä suhteessa Dell Hymesiin, joka viitoitti tietä myöhemmälle tutkimukselle perustaessaan Language in Society -lehden vuonna 1972 (ks. Hymes 1972). Myös Bell asettaa puheenvuoronsa "Succeeding waves: Seeking sociolingustic theory for the twenty-first century" kulma- 
kiveksi Hymesin ohjelmanjulistuksen (1974) arvioidessaan alan nykytilaa. Bell esittelee konkreettisin luvuin, miten esimerkiksi indeksisyys on asiasanana noussut Journal of Sociolinguisticsissa vuosien mittaan moninkertaisiin lukemiin ja miten Eckertin lanseeraama näkemys "kolmannen aallon" sosiolingvistiikasta on ottanut tulta alleen jo kauan ennen kuin hänen vuonna 2005 julki panemansa artikkelikäsikirjoitus viimein vuonna 2012 virallisesti julkaistiin (Eckert 2012). Myös Johnstone viittaa Eckertin teorian ja ylipäätään tyylin käsitteen nousuun sosiolingvistiikassa ohi rakennelähtöisten kysymyksenasetteluiden. Bell nostaa edelleen joitakin kriittisiä huomioita Eckertin sosiolingvistiikan aaltoja koskevasta tulkinnasta - olematta kuitenkaan eri mieltä Johnstonen kanssa sosiolingvistiikan painopisteen muutoksesta kohti toimijuuden (agency) tutkimusta.

Couplandin päätäntöartikkelissa "Five M's for sociolinguistic change" kantavana ajatuksena on, että sosiokulttuurisella tai sosiaalisella muutoksella on oltava sosiolingvistisessä teoriassa keskeinen asema: ollakseen innovatiivinen ja maailman menossa kiinni sosiolingvistinen teoria ei voi ohittaa muutosta sen enempää suhteessa empiiriseen todellisuuteen kuin alan sisäiseen (meta)teoreettiseen kehitykseen. Artikkelin nimen viisi M:ää viittaavat teoksen painotusten mukaisesti 1) kielellisiin markkinoihin, 2) mobiliteettiin eli liikkuvuuteen, 3) modaliteetteihin, 4) mediaan ja medioitumiseen sekä 5) metakommunikaatioon.

Kysymys teoriasta ja metateoriasta on ollut ja on yhä erityisen olennainen empiiriselle sosiolingvistiikalle, sillä kuten Coupland teoksen johdannon ensi riveillä toteaa (s. 1), jokaisella kielenkäyttäjälläkin on teoria kielestä. Tämä näkökulma jää kuitenkin teoksessa, yllättävää kyllä, varsin vähälle huomiolle. Kieliasennetutkimuksen perinteissä on korostettu kieliyhteisöissä vellovien sosiaalipsykologisten ja kognitiivisten prosessien keskeisyyttä sosiolingvistisessä teorianmuodostuksessa (ks. esim. Garrett 2001; Preston 2011). Tähän ei artikkeleissa kuitenkaan eksplisiittisesti tartuta, vaikka juuri sosiaaliseen muutokseen keskittyvässä teoksessa se olisi ollut hyvin perusteltua. Ilmiölähtöisesti rakennetun artikkelikokoelman ideana ei ymmärrettävästi ole ollut traditiolähtöinen käsittely, mikä mahdollisesti selittää kielenkäyttäjien näkökulman jäämistä viidennessä osassa tarkasteltujen yleistajuistamisnäkökulmien tasolle. Kieli-ideologioihin kiinnittyvien tutkimusintressien nousu ja kieli-ideologiset havainnot ovat kokoelmassa tosin monin paikoin esillä. Useammankin osan sisään olisi silti saattanut kuvitella luvun, jossa olisi voitu tarkastella kriittisesti kielellisen evaluaation ja tietoisuuksien tutkimisen kehitystä ja tämän välttämättömyyttä osana sosiolingvististä tutkimusagendaa, johon se on Labovin klassisista tutkimuksista lähtien sisältynyt.

\section{Lopuksi}

Jokainen sosiolingvisti voi nähdä Couplandin toimittamassa teoksessa aukkonsa, mutta teos ansaitsee silti kiitoksen jäntevästä, kekseliäällä otteella suunnitellusta ja hyvin toimitetusta kokonaisuudesta. Sosiolingvistiikasta kokonaiskäsitystä havittelevalle opiskelijalle suosittelen tätä teosta varovaisesti; lukeminen kannattaa ehkä aloittaa takaperoisesti teoksen viimeisestä osasta. Empiriaa on artikkeleiden käsittelyssä tarkoituksellisen säästeliäästi, mikä käytännössä tarkoittaa sitä, että valtaosa artikkeleista liikkuu tasolla, joka edellyttää alan traditioiden ja aiempien teoreettisten keskustelujen jonkinasteista tuntemusta. Perusteellista kokonaiskuvaa sosiolingvistiikasta ei tämänkään teoksen pohjalta saa, mutta jos tällaisen hahmotuksen toivossa olisi valittava luettavaksi vain yksi teos, tämä olisi varteenotettava ehdokas. Pelkästään kokoelman sisällysluettelon vilkaisu riittää 
antamaan tuntumaa siihen ilmiöpohjaisuuteen ja pinnalla olevien teoreettismetodologisten keskustelujen kärkeen, joka 2010-luvun sosiolingvistiikassa on kansainvälisesti tapetilla. Teoksen viimeisen osan artikkelit ovat tässä suhteessa informatiivisia ja kiinnostavalla tavalla reflektiivisiä.

Teos auttaa kontekstualisoimaan kotimaisia tai kielikohtaisia traditioita laajaan kansainväliseen tutkimuskenttään, joka väistämättä on volyymiltään ja siten myös lähestymistavoiltaan monimuotoisempi kuin paikallisten tiedeyhteisöjen kysymyksenasettelut ja tuotannot. Horisonttia voivat sumentaa myös paradigmaattiset rajat, jotka kansallisten tutkimusyhteisöjen sisällä ovat historiallisista syistä keskenään erilaisia. Fennistisen sosiolingvistiikan kuva on tänä päivänä monipuolisempi kuin vielä pari vuosikymmentä sitten, jolloin ala helposti miellettiin vielä etupäässä dialektologisen perinteen jatkajana näyttäytyväksi variaatioanalyysiksi (ks. Nuolijärvi 2000). Etnometodologinen keskustelunanalyysi on pitkään mieltynyt ja yhä mieltynee sosiolingvistiikasta erilliseksi perinteeksi, vaikka sosiolingvististen kysymyksenasettelujen monimuotoistuessa ja muokkautuessa yhä enemmän vuorovaikutukseen ja tyyleihin liittyvien kysymysten suuntaan perinteet ovat lähentyneet ja niitä on myös tietoisesti tuotu yhteen (ks. esim. Sorjonen, Rouhikoski \& Lehtonen toim. 2015).

Kokonaisuutena Couplandin toimittama teos maalaa sosiolingvistiikan alalla hiljalleen tapahtunutta siirtymää lingvistiikan sisäisten kysymysten motivaatioista kohti yhteiskunnallisempia ja sosiaaliseen toimintaan liittyviä kysymyksenasetteluja. Tähän liittyy teoreettisesti vilkas keskustelu, joka on saanut sosiolingvistejä myös lähitieteiden klassikoiden (uudelleen)avaamisen äärelle. Couplandin teoksesta saa monipuolista tuntumaa siihen, miten nykysosiolingvistiikan keinoin voidaan tutkia yhteiskunnallisen muutoksen ilmiöitä ja miten alan johtavat tutkijat asemoituvat suhteessa niihin. Näin teoksessa pureudutaan myös niihin perimmäisiin taustaoletuksiin kielestä ja yhteiskunnasta, jotka jokaisen aloittelevankin tutkijan on syytä tunnistaa.

\section{JOHANNA VAATTOVAaRA} etunimi.sukunimi@tuni.fi

Kirjoittaja on suomen kielen apulaisprofessori Tampereen yliopistossa.

\section{Kirjallisuus}

Auer, Peter - Schmidt, Jürgen Erich (toim.) 2010: Language and space. An international handbook of linguistic variation. Volume 1. Theories and methods. Berlin: Walter de Gruyter.

Bell, Allan 1984: Language style as audience design. - Language in Society 13 s. 145-204.

Blommaert, Jan - Rampton, Ben 2011: Language and superdiversity. - Diversities 13 (2) s. 1-22.

Chambers, J. K. 2009 [1995]: Sociolinguistic theory. Linguistic variation and its social signifigance. Oxford: Blackwell.

Coupland, Nikolas - Sarangi, SriKAnt - Candlin, Cristopher N. (toim.) 2001: Sociolinguistics and social theory. London: Longman.

Dufva, Hannele - Aro, Mari - Suni, Minna - Salo, Olli-Pekka 2011: Onko kieltä olemassa? Teoreettinen kielitiede, soveltava kielitiede ja kielen oppimisen tutkimus. - Esa Lehtinen, Sirkku Aaltonen, Merja Koskela, Elina Nevasaari \& Mariann Skog-Södersved (toim.), AFinLA-e. Soveltavan kielitieteen tutkimuksia 3 s. 22-34.

Eckert, Penelope 2012: Three waves of variation study. The emergence of meaning in the study of sociolinguistic variation. - Annual Review of Anthropology 41 s. $87-100$. 
FigueroA, Esther 1994: Sociolinguistic metatheory. Oxford: Pergamon.

Foucault, Michel 1980: Power/Knowledge. Selected interviews and other writings 1972-1977. Toimittanut Colin Gordon. Kääntäneet Colin Gordon, Leo Marshall, John Mepham \& Kate Soper. New York: Pantheon books.

Garrett, Peter 2001: Language attitudes and sociolinguistics. - Journal of Sociolinguistics 5 s. 626-631.

Gumperz, John 1982: Discourse strategies. Cambridge: Cambridge University Press.

Halonen, Mia - VaAttovaara, JohanNA 2017: Tracing the indexicalization of the notion "Helsinki s". - Linguistics 55 S. 1169-1195.

Hymes, Dell 1972: Editorial introduction to Language in society. - Language in Society 1 s. 1-14.

- 1974: Foundations of sociolinguistics. An ethnographic approach. Philadelphia: University of Pennsylvania Press.

Lehtonen, Heini 2015: Tyylitellen. Nuorten kielelliset resurssit ja kielen sosiaalinen indeksisyys monietnisessä Helsingissä. Suomen kielen, suomalais-ugrilaisten ja pohjoismaisten kielten ja kirjallisuuksien laitos. Helsingin yliopisto. http://urn.fi/

URN:ISBN:978-951-51-1333-7.

Nuolijärvi, Pirkкo 2000: Sosiolingvistiikka kielentutkimuksen kentässä. Kari Sajavaara \& Arja Piirainen-Marsh (toim.), Kieli, diskurssi \& yhteisö s. 13-38. Soveltavan kielentutkimuksen teoriaa ja käytäntöä 2. Jyväskylä: Jyväskylän yliopisto, Soveltavan kielentutkimuksen keskus.

Preston, Dennis R. 2011: The power of language regard. Discrimination, classification, comprehension, and production.

- Dialectologia s. 9-33.

Silverstein, Michael 2003: Indexical order and the dialectics of sociolinguistic life. - Language and Communication 23 S. $193-229$.

Sorjonen, Marja-Leena - Rouhikoski, Anu - Lehtonen, Heini (toim.) 2015: Helsingissä puhuttavat suomet. Kielen indeksisyys ja sosiaaliset identiteetit. Suomalaisen Kirjallisuuden Seuran Toimituksia 1310. Helsinki: Suomalaisen Kirjallisuuden Seura.

Vertovec, Steven 2007: Super-diversity and its implications. - Ethnic and Racial Studies 30 s. 1024-1054.

\section{Vuorovaikutuksen näkökulmia imperatiivisten vuorojen rakenteeseen ja käyttöön}

\begin{abstract}
Marja-Leena Sorjonen, Liisa Raevaara \& Elizabeth Couper-Kuhlen (toim.): Imperative turns at talk. The design of directives in action. Studies in Language and Social Interaction 30. Amsterdam: John Benjamins 2017. 435 s. ISBN 978-90-272-2640-2.
\end{abstract}

Imperative turns at talk: The design of directives in action on mittava imperatiivisia vuoroja vuorovaikutuksessa analysoiva kokoomateos. Marja-Leena Sorjosen, Liisa Raevaaran ja Elizabeth Couper-Kuhlenin toimittama teos koostuu johdannon ja epilogin lisäksi kahdestatoista luvusta. Analyysi kohdistuu hyvin monentyyppisiin kasvokkaista ja puhelinvälitteistä vuorovaikutusta edustaviin aineistoihin, joita analysoidaan multimodaalisesta näkökul- 